\title{
Canine mammary tumors contain cancer stem-like cells and form spheroids with an embryonic stem cell signature
}

\author{
MARIA FERLETTA ${ }^{1}$, JAN GRAWÉ ${ }^{1}$ and EVA HELLMÉN ${ }^{*, 1,2}$ \\ 'Uppsala University, Department of Immunology, Genetics and Pathology and ${ }^{2}$ Swedish University of Agricultural \\ Sciences, Department of Anatomy, Physiology and Biochemistry, Uppsala, Sweden
}

\begin{abstract}
We have investigated the presence of tentative stem-like cells in the canine mammary tumor cell line CMT-U229. This cell line is established from an atypical benign mixed mammary tumor, which has the property of forming duct-like structures in collagen gels. Stem cells in mammary glands are located in the epithelium; therefore we thought that the CMT-U229 cell line would be suitable for detection of tentative cancer stem-like cells. Side population (SP) analyses by flow cytometry were performed with cells that formed spheroids and with cells that did not. Flow cytometric, single sorted cells were expanded and re-cultured as spheroids. The spheroids were paraffin embedded and characterized by immunohistochemistry. SP analyses showed that spheroid forming cells (retenate) as well as single cells (filtrate) contained SP cells. Sca1 positive cells were single cell sorted and thereafter the SP population increased with repeated SP analyses. The SP cells were positively labeled with the cell surface-markers CD44 and CD49f (integrin alpha6); however the expression of CD24 was low or negative. The spheroids expressed the transcription factor and stem cell marker Sox2, as well as Oct4. Interestingly, only peripheral cells of the spheroids and single cells were positive for Oct4 expression. SP cells are suggested to correspond to stem cells and in this study, we have enriched for tentative tumor stem-like cells derived from a canine mammary tumor. All the used markers indicate that the studied CMT-U229 cell line contains SP cells, which in particular have cancer stem-like cell characteristics.
\end{abstract}

KEY WORDS: canine mammary tumor, stem-like, SP

\section{Introduction}

Mammary stem cells are demonstrated both in mice and in humans (Alvi, et al., 2003, Clarke, et al., 2005, Clayton, et al., 2004, Dontu, et al., 2003, Liao, et al., 2007, Shackleton, et al., 2006, Sleeman, et al., 2006, Stingl, et al., 2006, Villadsen, et al., 2007). In accordance with this, breast cancer stem cells are characterized (Al-Hajj, et al., 2003, Wright, et al., 2008, Zucchi, et al., 2007). Cells that efflux the Hoechst 33342 dye can be detected and sorted in a flow cytometer. These cells are named side population (SP) cells and are suggested to correspond to stem cells in the bone marrow and in the mammary gland (Clarke, et al., 2005, Dontu, et al., 2003). In the cited studies of breast cancer stem cells, SP analyses are performed with or without complementary studies of cell surface-markers or tumorigenic studies in mice. The SP analysis technique has been questioned due to varying results (Smalley and Clarke, 2005) and also for affect cell differentiation (Adamski, et al., 2007). However, it is stated that the transcriptional profile of mammary SP cells has an enrichment of genes GO annotated into: cell cycle regulation and checkpoints, multidrug resistant transporters, organogenesis and vasculogenesis. The non-SP cells on the other hand, has up-regulated genes enriched in the GO category of cellular organization and biogenesis. This GO category included basal epithelial markers, p63, smooth muscle actin, integrin $\alpha 6$, CK14, CK8 and CD24, thus markers for progenitor cells, luminal and basal mammary epithelial cells (Behbod, et al., 2006). The stem cell antigen sca-1 was introduced as a marker for mouse mammary cells. Sca-1 positive cells are localized to the luminal epithelium, which are progesterone negative and do not bind peanut lectin and they have an increased regenerative potential when transplanted into cleared mammary fat pads in host mice. It was concluded from this study that sca-1 positive cells correspond

Abbreviations used in this paper: SP, side population.

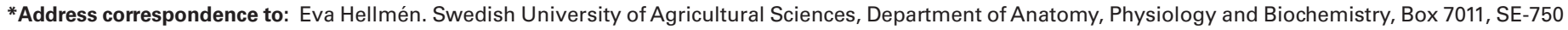
07 Uppsala, Sweden. Tel: +46-18-672-128. Fax: +46-18-672-111. e-mail: Eva.Hellmen@slu.se

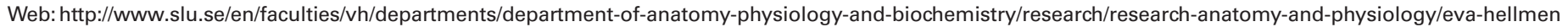



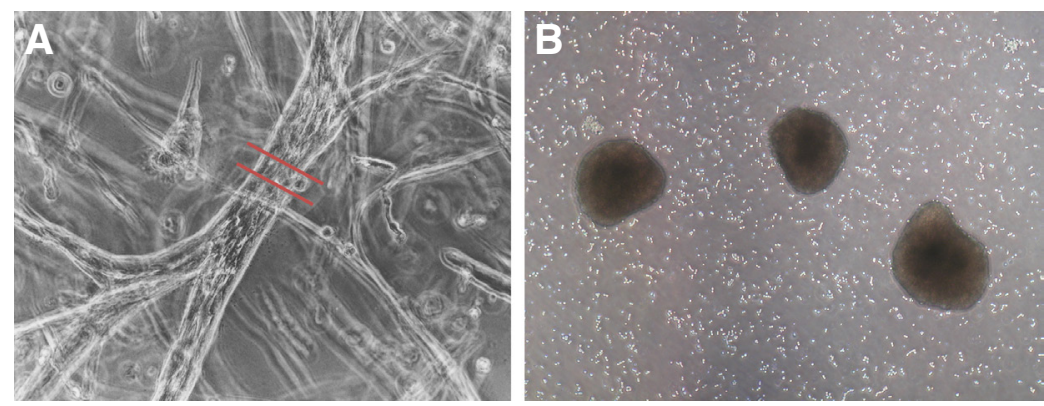

Fig. 1. CMT-U229 cells passage $\mathbf{1 0 8}$, in collagen type I culture. The red bars indicate an area cut for subcloning to form CMT-U229 av/2 (A). CMT-U229 avl2 cells in spinner flask culture forming spheroids. Note the single cells in between the spheroids (B).
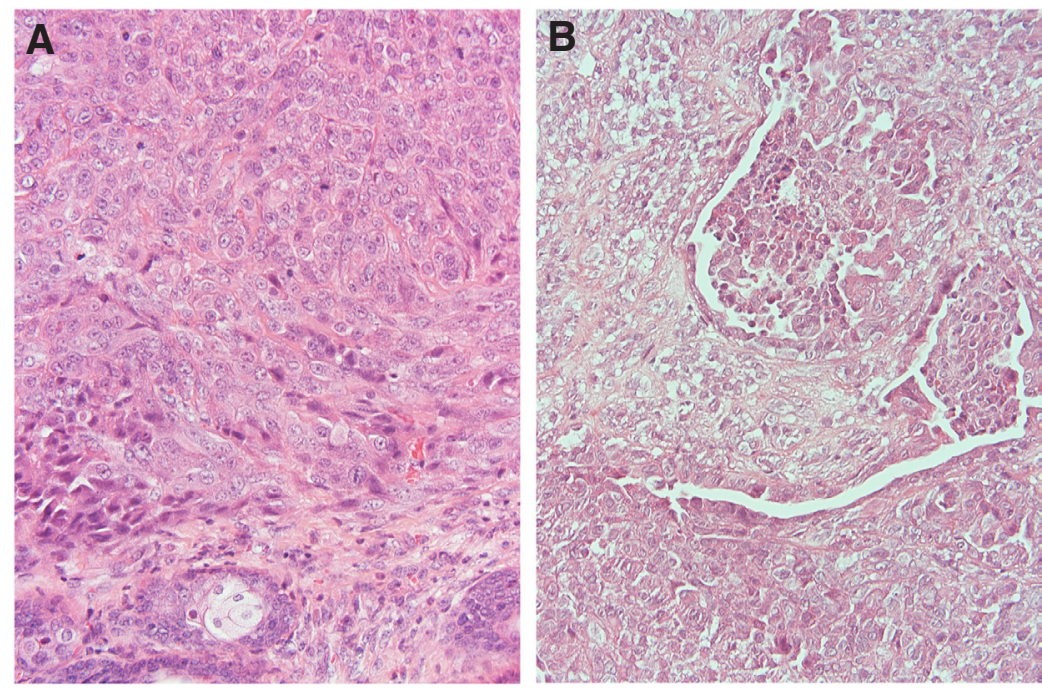

Fig. 2. Light micrographs of formed tumors from the CMT-U229 avl2 cells in nude mice. Simple carcinoma of solid type from CMT-U229 avl2 cells at passage 131 (A) Simple carcinoma of tubulopapillary type from CMT-U229 av/2 cells at passage 133 (B), (A-B objective $\times 20)$.

to mouse mammary progenitor cells (Welm, et al., 2002). Chen et al., showed that sca-1 positive cells in an immortalized mouse mammary gland cell line are resistant to radiation and self-renewal and the sca- 1 positive cells can be enhanced by $\beta$-catenin (Chen, et al., 2007). The characteristic of efflux the Hoechst dye is also shown in multidrug resistance. It is reported that the transporter breast cancer resistance protein BCRP (ABCG2) mediate multidrug resistance and $A B C G 2$ is expressed in SP cells (Doyle and Ross, 2003). Comparison of SP cells and ABCG2+/- cancer cells showed that only the SP cell population in the studied glioma U373 cell line as well as in the breast cancer MCF7 cell line enriched with tumorigenic stem-like cells (Patrawala, et al., 2005). ABC-transport proteins are also detected, by RT-PCR, in canine mammary tumors (Honscha, et al., 2009). Interestingly, recently it is shown that integrin $\alpha 6$ (CD49f) was necessary for tumorigenicity of a subpopulation of MCF7 cells. The knockdown of ITGA6 caused the cells to lose their capacity to form spheroids i.e. single cells) respectively. and their ability to form tumors in mice (Cariati, et al., 2008). In another study, breast cancer samples grown as spheroids, showed that CD44+/CD24- breast cancer initiating cells expressed the transcription factor Oct4 (Ponti, et al., 2005). Further, very encouraging results are shown with oncolytic adenoviruses that killed breast cancer initiating CD $44^{+} \mathrm{CD} 24^{- \text {llow }}$ cells. Cancer cells from pleural effusions expressed Oct4, Sox2 and effluxed Hoechst. The viral treatment even prevented tumor formation in mice (Eriksson, et al., 2007). Further, sphere formation is also described in canine mammary glands and tumors (Cocola, et al., 2009, Michishita, et al., 2006).

In the present work we have studied the presence of tentative cancer stem-like cells in the canine mammary tumor cell line CMT-U229. This cell line, which we have established from an atypical benign mixed mammary tumor, has the property to form duct-like structures in collagen gels (Hellmen, 1992). Since stem cells in the mammary gland are located to the epithelium we thought this cell line would be interesting to use for detection of tentative mammary tumor stem cells. In the case that side population cells correspond to stem cells we have enriched tentative tumor stem-like cells from the subcloned CMT-U229 avl2 cell line. All the cellular markers that we have used indicate that the studied cell line, in particular when enriched for the SP cells, have stem cell characteristics and that the studied cells are robust and plastic.

\section{Results}

\section{Spheroid formation}

In this study the CMT-U229 canine mammary tumor cell line is used to examine the ability of mammary tumor cells to form spheroids, which is a general accepted criterion of cancer stem-like cells (Welm, et al., 2002). The CMTU229 cells were first subcloned by cutting out a piece of a formed duct from a collagen type I culture, the used cell clone is named CMT-U229 avl2 (Fig. 1 A). The CMT-U229 avl2 cells formed spheroids in rotating spinner flask cultures. In addition to formed spheroids single to doublet cells were present in the media (Fig. $1 \mathrm{~B}$ ). There appears to be a balance between the number of spheroids and the number of single cells i.e. high number of spher-

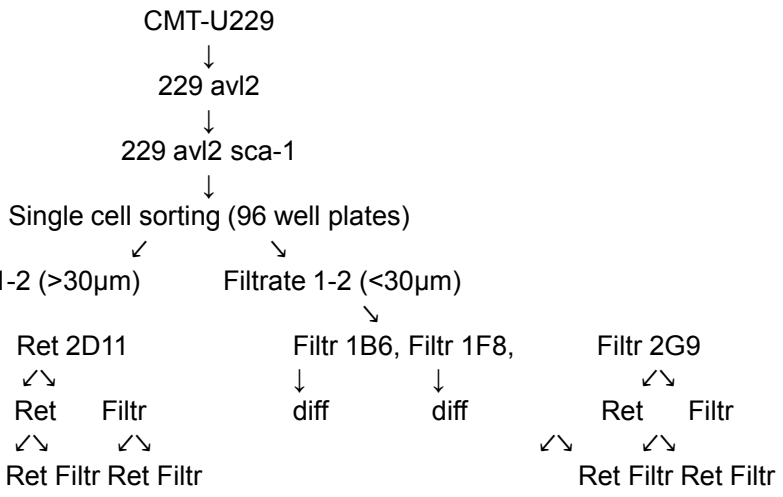

Fig. 3. The experimental design of the side population (SP) analyses. Single cell sorting was

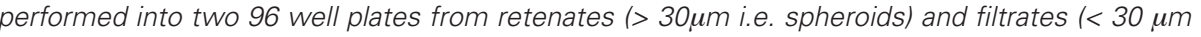


oids gave few single cells whereasa high number of single cells gave few spheroids. We optimized the time for spinner flask cultures to 7 days and this balance was still observed.

\section{CMT-U229 cells are able to form mammary tumors in vivo}

To investigate the tumorigenic capacity of the CMT-U229 avl2 cell line, cells were subcutaneously reinjected into the flank of nude mice. All four injected mice formed tumors within three to 6 weeks with a tumor size of $1 \mathrm{~cm}$ in diameter. Two mice were inoculated with CMT-U229 avl2 cells at passage 131, these tumors showed a histology typical of a simple carcinomas of solid type

(Fig. 2A). Whereas the tumors from CMT-U229 avl2 cells at passage 133 contained characteristics of simple carcinomas of tubulo-papillary type (Fig. 2 B). These results indicate that the CMT-U229 avl2 cells still are tumorigenic by forming carcinomas in nude mice.

\section{Side population cells were present in both retenate and filtrate cell fractions}

Next we wanted to examine the presence of side population cells in the spheroids (retenates) as well as in the single cell fraction (filtrate) of the CMT-U229 avl2 cells. The experimental set up is summarized in Fig. 3. The CMT-U229 avl2 cells were first sorted by

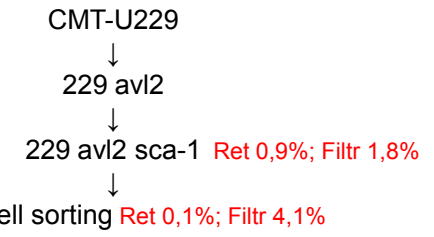

Single cell sorting Ret $0,1 \%$; Filtr $4,1 \%$

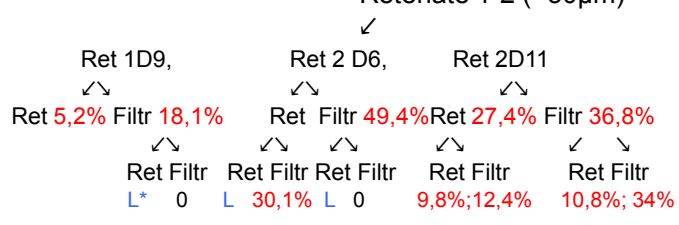

Filtrate $1-2(<30 \mu \mathrm{m})$

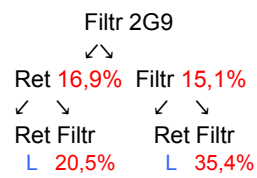

Fig. 4. Results of the side population (SP) analyses in figures (in red). Note the increasing number of $S P$ cells, demonstrating an enrichment of these cell fractions. $L$, large; by time the spheroids in the retenate fractions were too large to get into single cells by trypsin; 0 , too few; when the spheroids were large the cells in the filtrate fractions were too few to be analyzed.

spheroids were too large and the cells were not separated after trypsin treatment (Figs. 6 B,D). Taken together these results indicate that it is possible to enrich for the SP cells.

\section{PKH26 labeling indicated both "monoclonal" and "polyclonal" spheroid formation}

To study the formation of spheroids we used the PKH26 dye to label the cell membrane of SP and non-SP cells respectively. The PKH26 staining will decrease for each cell division and thus spheroids formed from one single cell "monoclonal" have a stronger labeling in the centre of the spheroid compared to the periphery. If

flow cytometry in regard to the expression of the stem cell marker sca-1 (Welm, et al., 2002). About 5\% of the analyzed filtrate cells were positively labeled and theses cells were sorted. Thereafter the side population analyses were performed. Fig. 4 shows the results from the side population analyses in numbers. Initially side population cells from the sca-1 positive fraction contained $0.9 \%$ SP (retenate) cells and $1.8 \%$ filtrate cells and were recultured in spinner flasks as described above. The SP analyses were repeated and the percentage of SP cells in the retenate decreased to $0.1 \%$ meanwhile in the filtrate the percentage of SP cells increased to $4.1 \%$ (Figs. 4 and 5). We continued to single cell sort these SP cells (into two 96 well plates each). In total, cell growth was observed in 64 wells originating from the retenate cells and in 45 cell clones grown from the filtrate cells (in total $28,4 \%$ of the cells continued to grow). Three cell clones originating from the retenate (Ret 1D9, Ret $2 \mathrm{D} 6$ and Ret 2D11) respectively from the filtrate (Filtr 1B6, Filtr 1F8 and Filtr 2G9) were expanded and SP analyzes were repeated. Interestingly, the number of SP cells had increased to a very large extent. Filtrate cells originating from the studied retenate clones (Ret 1D9, Ret 2D6 and Ret 2D11) is now containing $18.1 \%$ to $49.4 \%$ SP cells and the analyzed filtrate cells originating from the investigated filtrate cell clone (Filtr 2G9) contains 15.1 to $35.4 \%$ of SP cells (Figs. 4, 6 A,C). In contrast, cells from the Filtr $1 \mathrm{~B} 6$ and Filtr 1F8 clones ceased to proliferate and seemed to be differentiated (not shown). Further, the retenate cells i.e. cells derived from spheroids were after repeated sorting no longer possible to get into single cell suspension. The
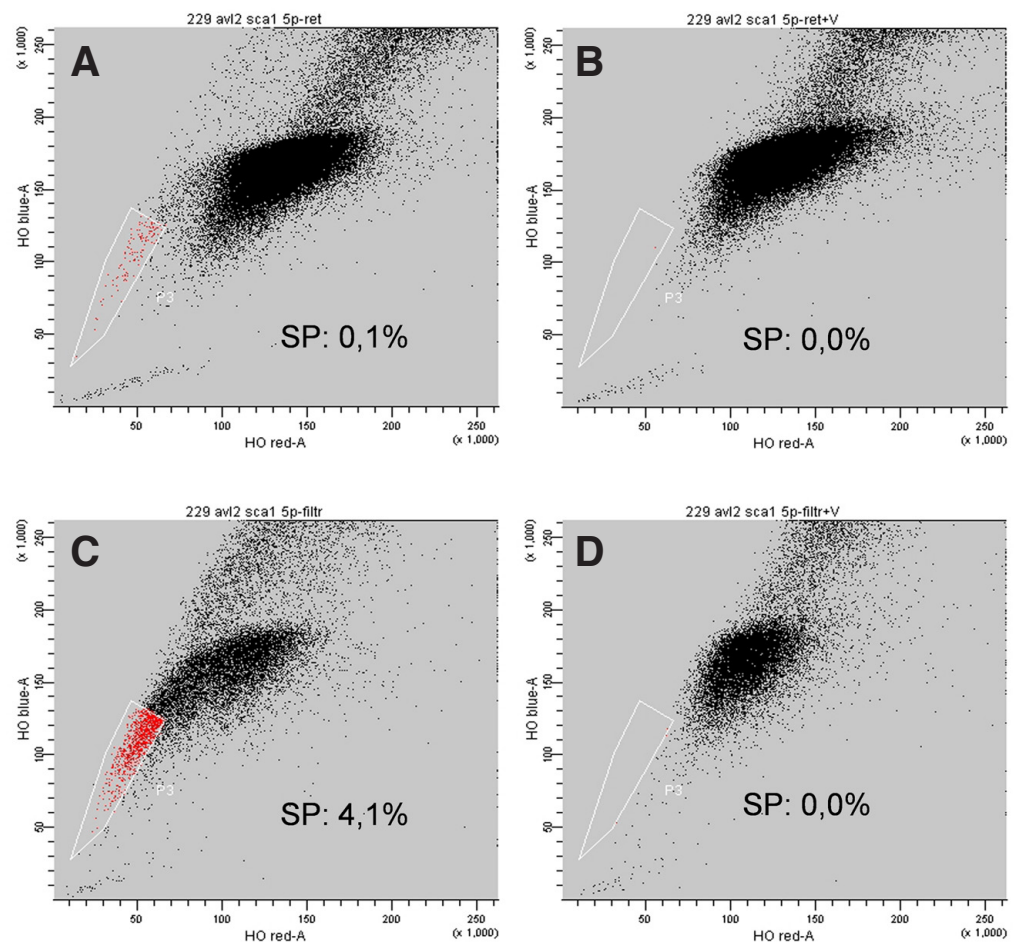

Fig. 5. Side population (SP) analysis of sca1 positive CMT-U229 avl2 cells Single cell sorting was done on SP cells from the retenate fraction (A) as well as on the filtrate fraction (C). Verapamil totally blocked efflux of the Hoechst dye; retenate fraction (B), filtrate fraction (D). 

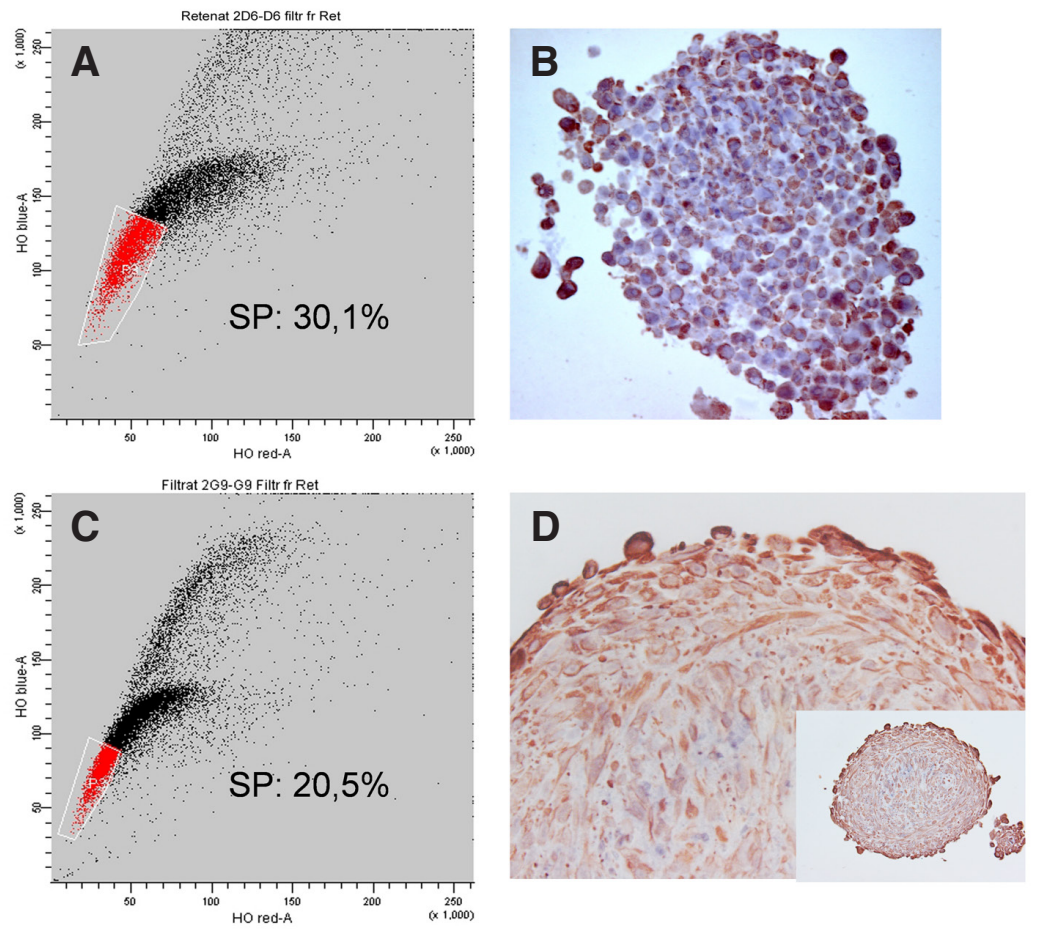

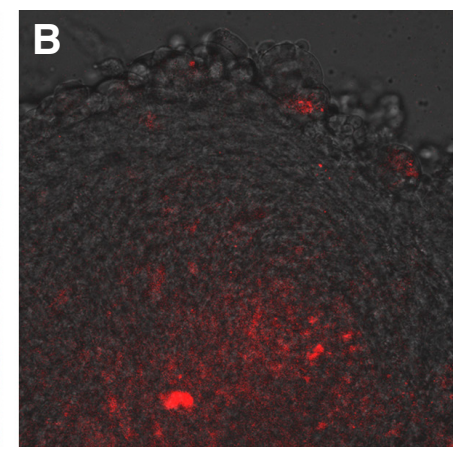

Fig. 7. PKH26 labeled CMT-U229 avl2 cell spheroids. A spheroid derived from SP cells (A) and from non-SP cells (B) respectively, cultured for 12 days (objective $x$ 20). The distribution of PKH26 in the spheroids is red and the distribution of labeled cells is seen both in the periphery and the centre of (A) whereas it is more concentrated to the centre of (B). This indicates that the spheroid in (B) has a monoclonal origin but the one in (A) is polyclonal.
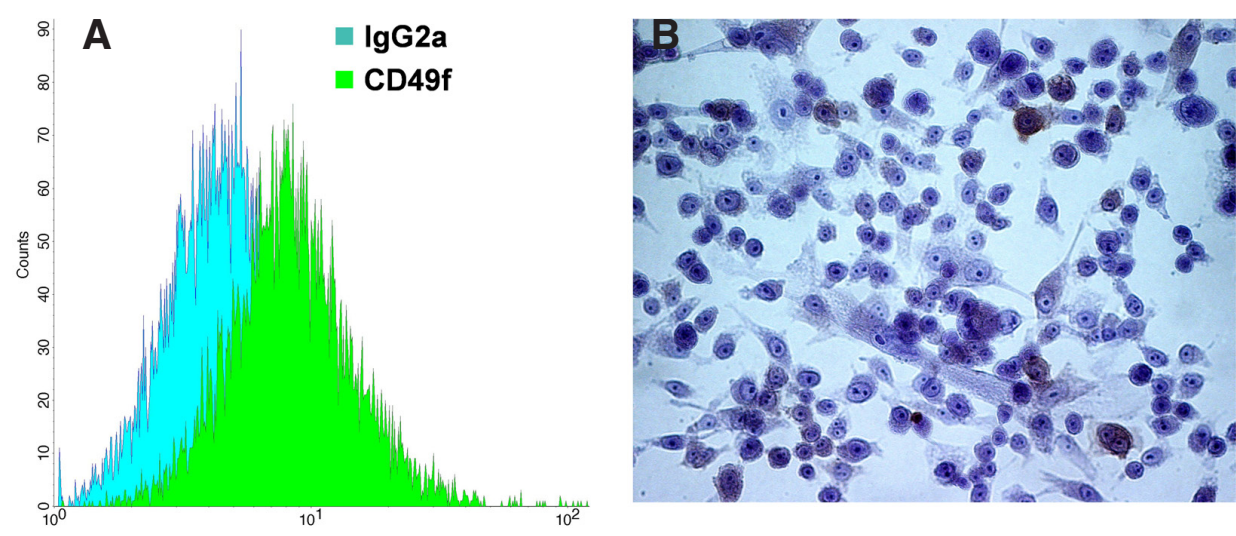

Fig. 6. Enrichment of side populations (SP). Single sorted cells were expanded in vitro and the SP analyses were repeated. The fraction of SP cells from the single cell sorted retenate as well as filtrate cells showed a strong increase of SP cells $(\mathbf{A}, \mathbf{C})$ (see red). (B,D) Retenates i.e. spheroids that were too large to be separate by trypsin (vimentin labeled spheroids). In (B,D) objective $x 40$ was used whereas in (D), inset objective $x 20$ was used. This demonstrates the large size of some spheroids and that most cells were vimentin positive.

the spheroids are formed by cell aggregation "polyclonal" aggregates, then strongly labeled cells will be found randomly in the spheroid. Actually, we found both types of spheroids and interestingly originating from both SP and non-SP cells (Figs. 7 A,B). For comparison, we PKH26 labeled cells that grew on agarose-coated dishes, to avoid attachment to the bottom, and a similar pattern was observed but the "polyclonal" spheroids increased in this system compared to spinner flask cultures (not shown). Our results suggest, at least in this experimental set up, that the spheroid forming assay is not a criteria reserved for SP cells only.

\section{CD44 and CD49f are expressed on the SPcells and only a few cells stained positive for CD34 as well as CD24}

To study the expression of different cell surface-markers on the SP cells we initially labeled them with antibodies against CD10, CD34 and CD44 and analyzed them by flow cytometry. No cells expressed CD10, a few cells (2-5\%) expressed CD34 whereas most of the cells were positive for CD44 (80-95\%) (not shown). CD34 has been shown to be expressed on stem cells as well as progenitor cells (Schulenburg, et al., 2006). Further, Al-Hajj et al., has shown that human breast tumor cells expressing CD44+ and CD24-low are very prone to recapitulate the mammary tumors when re-injected into mice (Al-Hajj, et al., 2003). We continued to study the expression of CD24 and CD49f and only a few cells stained positive with the CD24 antibody (not shown) whereas a population of the cells was labeled with the CD49f antibody (Figs, 8 A,B). CD49f is suggested to be involved in mammary gland progression (Woodward, et al., 2005). The expression profile found on the SP cells CD10 low/CD34 $/$ $\mathrm{CD}_{4}{ }^{+} / \mathrm{CD} 24^{\text {low }}$ and $\mathrm{CD} 49 \mathrm{f}^{+}$support the idea that mammary tumor cells from canine do contain a population of cancer stem-like cells.

\section{Spheroid cells as well as single cells express Sox2 and Oct4}

CD133 is suggested to be a marker for tumor initiating cells as well as cells more resistant to treatment both in gliomas and in breast cancer (Wright, et al., 2008). We continued to investigate the presence of CD133. We performed SP analysis on CMT-U229 avl2 cells at passage 11 and sorted both retenate $(2.6 \%)$ and filtrate $(0.6 \%)$ cells that were positively labeled with the CD133 antibody. The retenate cells survived and they were

Fig. 8. Expression of CD49f in CMT-U229 cells. Histogram comparing results, from flow cytometry (FACSort) of CD49fand lgG2a, showed a higher expression of CD49f compared to the negative control (IgG2a), (A). Immunocytochemistry was also positive for CD49f (B), lobjective $x$ 20), but not for CD24 (not shown). 


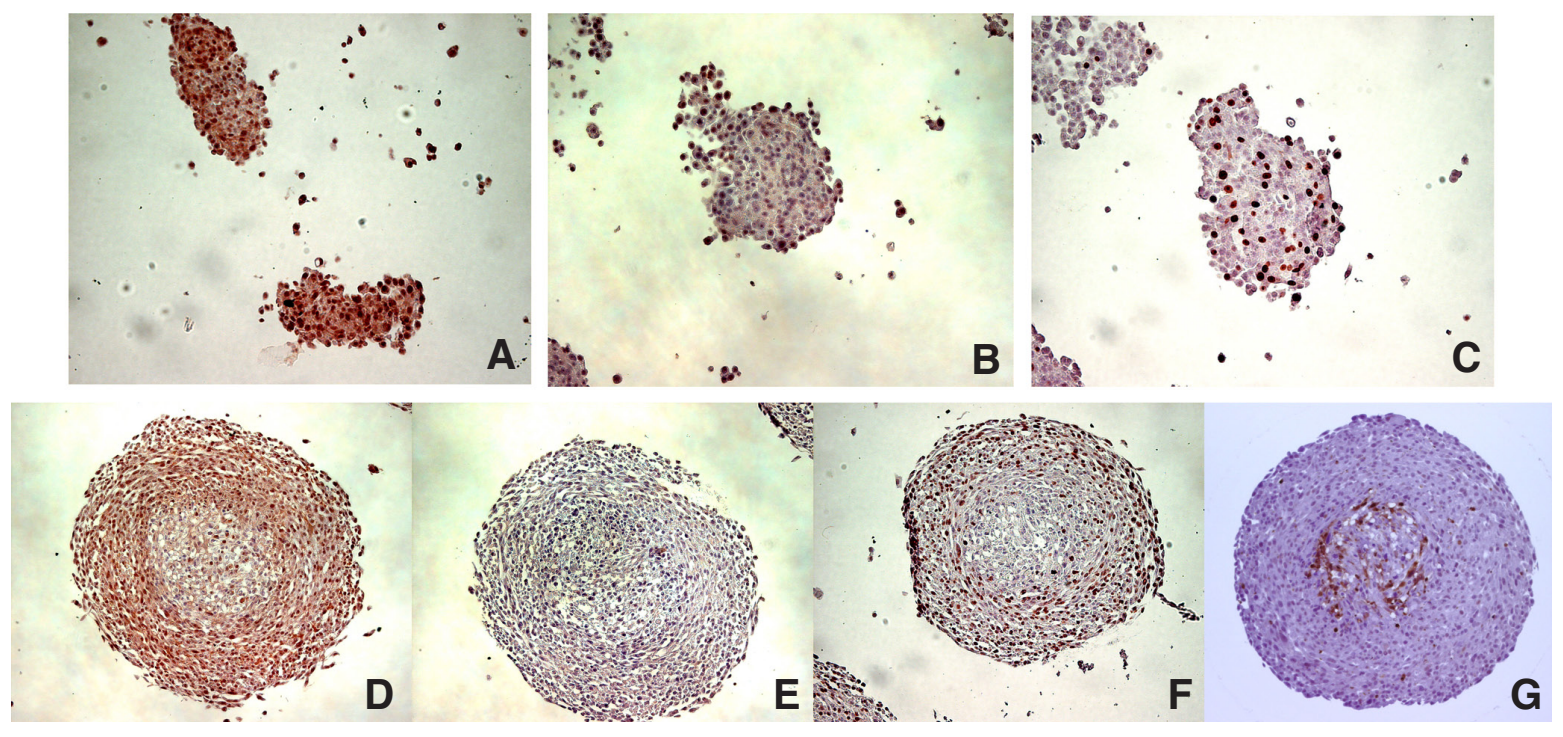

Fig. 9. CMT-U229 avl2 sca-1+ cells further sorted for CD133+ and cultured as spheroids in spinner flasks or in Hydro Cell plates. Light micrographs of CMT-U229 av12 sca-1 + cells (passage 11) cultured as spheroids in agarose-coated petri dishes for 7 days (A-C) or further sorted for CD133+ and cultured in Hydro Cell plates for 21 days (D-G): stained against Sox2 (A,D); Oct-4 (B,E); Ki-67 (C,F); and Asp175 (Cleaved Caspase-3), (G). Note that only the peripheral and single cells were labeled with the Oct4 antibody $(\mathbf{B}, \mathbf{E})$ whereas most cell nuclei were labeled with the Sox2 antibody $(\mathbf{A}, \mathbf{D})$. The labeling pattern for Ki-67 and Asp175 was the opposite i.e. Ki-67 positive cells were located in the outer parts whereas the relatively few Asp175 positive cells mainly were found in the centre of the spheroids (F,G), (A-G objective x 20).

sorted again for CD133 positivity (4.1\%). These sorted cells were further cultured and the CD133 sorting procedure was repeated but this time the CD133 positive cells (1.4\%) were sorted directly into a 24 well low binding Hydro Cell plate. The sorted cells formed spheroids and were allowed to grow for 21 days (Figs. 9 D-G and 10 A-B). Next, we were interested to study whether the formed spheroids expressed stem cell markers. Immunohistochemistry stainings of Sox2 and Oct4 were performed on paraffin embedded spheroids, both from a 7 days agarose-coated dish culture and from Hydro Cell 21 day culture. For comparison the spheroids were stained with Ki-67 and Asp175. Merely cells in the periphery of the large spheroids and the nuclei of single cells stained positive to Oct4 (Fig. 9 B,E and Fig. 10A). On the other hand, Sox2 was expressed in the nuclei of most cells (Fig. 9 A,D and Fig. 10B). The expression pattern for Sox2 and Ki-67 corresponded in the Hydro Cell formed spheroids with positive cell nuclei in most cells except for the ones in the central parts of the spheroids (Fig. 9 C,F), which indicate that the Sox2 positive cells are proliferative. The expression of Sox 2 and Ki-67 were opposite to the location of the Cleaved Caspase-3 positive cells i.e. apoptotic cells that mainly were located in the centre of the spheroids (Fig. 9G). These observations suggest that enriching cells for the expression of CD133 is another way, in addition to the ability to efflux Hoechst, to substantiate the presence of cancer stem-like cells in the CMT-U229 avl2 cell line.

\section{Spheroid cells express Sox2 and Oct4 in different cell culture media}

In order to investigate the role of cell culture medium on spheroid formation, spheroids from CMT-U229 avl2 (passage 119) were cultured in spinner flasks for 7 days in enriched DMEM medium and in RPMI1640 medium plus 10\% FBS. However, the same staining pattern for Oct4 (Fig. 11 A,C) and Sox2 (Fig. 11 B,D) was observed irrespectively of cell culture medium. Notably, the morphology of the spheroids differed; spheroids cultured in enriched DMEM were more sparsely organized than the ones grown in RPMI that appeared denser (Fig. 11).

\section{Filtrate cells form spheroids but the trypsin treated spheroids failed to re-grow}

Next we wanted to examine how far it is possible to re-culture spheroid growing cells. CMT-U229 avl2 (passage 120) were cultured as spheroids. After 14 days of culture, the spheroids that were trypsin treated and re-cultured as retenate and filtrate, all
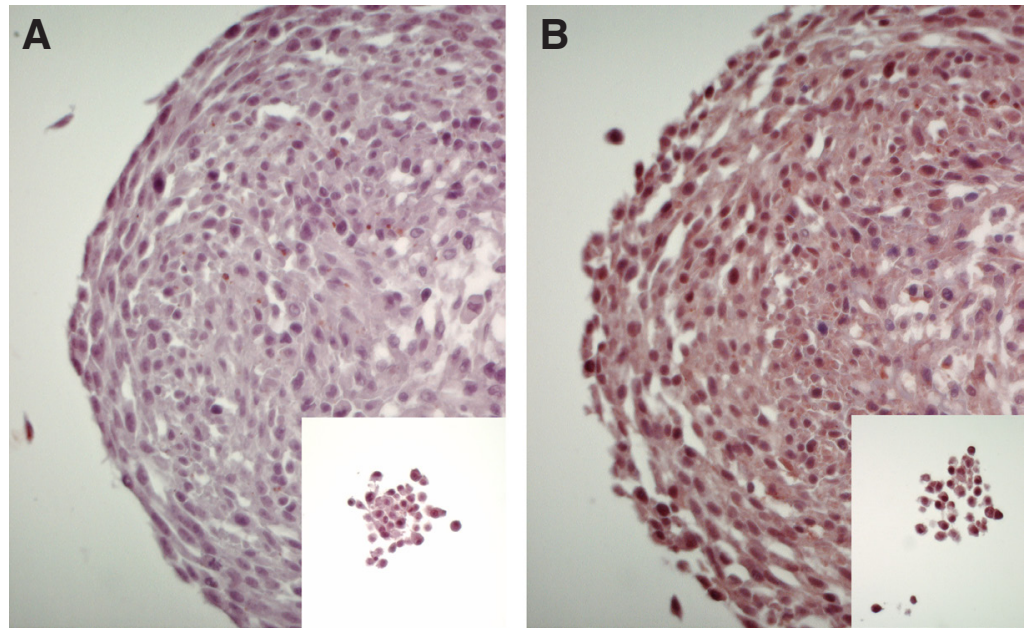

Fig. 10. CMT-U229 avl2 cells sorted for CD133+stained positive for Oct4 and Sox2. Light micrographs of CMT-U229 avl2 cells sorted for CD133+ cultured in Hydro Cell plates for 21 days: stained against Oct-4 (A); Sox2 (B). Note that only the peripheral and single cells (insets) were labeled with the Oct4 antibody (A) whereas most cell nuclei, except for cells in the central part, were labeled with the Sox2 antibody (B), (A, B objective $\times 20$ ). 

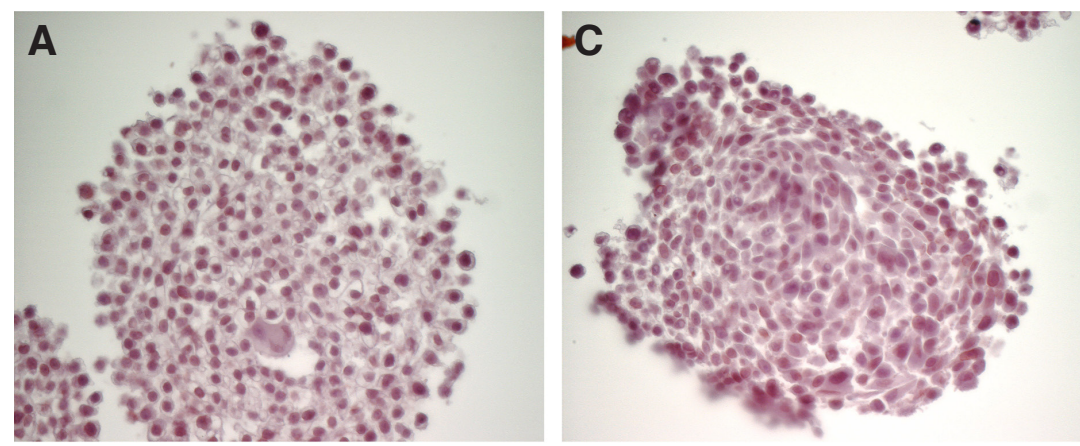

\section{Cancer stem-like cells do not form spheroids under serum free conditions}

Further we were interested to examine if cancerstem-like cells are that potent that they can grow under serum free conditions in RPMI1640 medium. CD133+ sorted retenate cells (passage 6) were cultured under serum free conditions in Hydro Cell plates but, the cells failed to grow. Only a few single cells were detected (not shown). In contrast, both spheroids and single cells were observed in all wells with serum-enriched medium (Fig. 13A, wells B2-4 and C1-4). Despite the number of seeded cells, at day 27 , plenty of spheroids
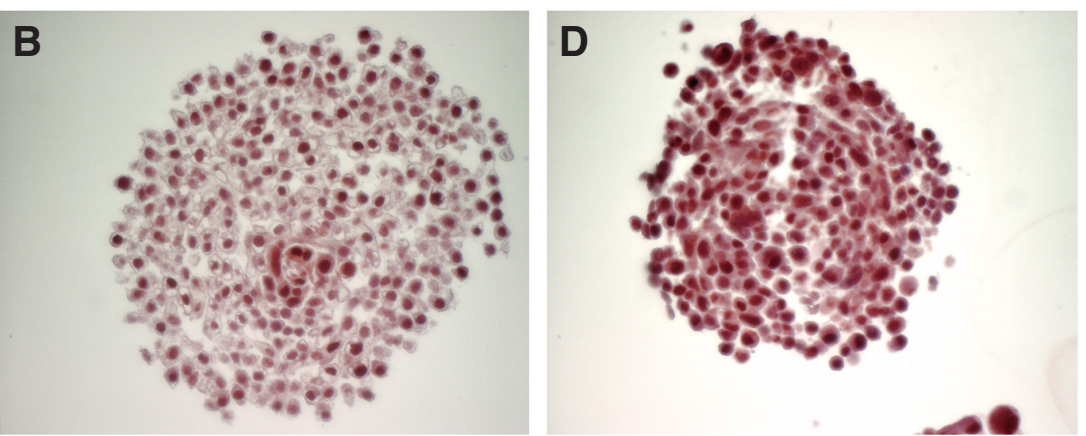

Fig. 11. Spheroid cells express Sox2 and Oct4 in different cell culture media. Light micrographs of CMT-U229 av12 cells at passage 119. Spheroids cultured in spinner flasks for 7 days in enriched DMEM medium stained for Oct4 (A) and Sox2 (B): cells cultured in RPMI1640 medium plus 10\% fetal bovine serum stained for Oct4 (C) and Sox2 (D). Note that the same staining pattern was observed irrespectively of cell culture medium, (A-D objective $\times 20$ ).

the cells re-grow (Fig. 12, wells 5-6 and 7-8). The spheroids were retreated with trypsin and re-cultured as retenate and filtrate. This time the cells from the retenate ceased to grow (Fig. 12, wells 9-10). Interestingly, in all wells with filtrate cells, new spheroids were formed (Fig. 12, wells 3-4, 7-8 and 11-12) and few single cells were observed.The yellow color of the medium indicates that the cells are viable and small spheroids can be seen in the lower part of these wells. This demonstrates that it is possible for cells in the filtrate fraction to form spheroids and to re-culture cells derived from spheroids to a certain level. The latter results are in agreement with the presence of apoptotic cells in the centre of spheroids (Fig. $9 \mathrm{G}$ ).

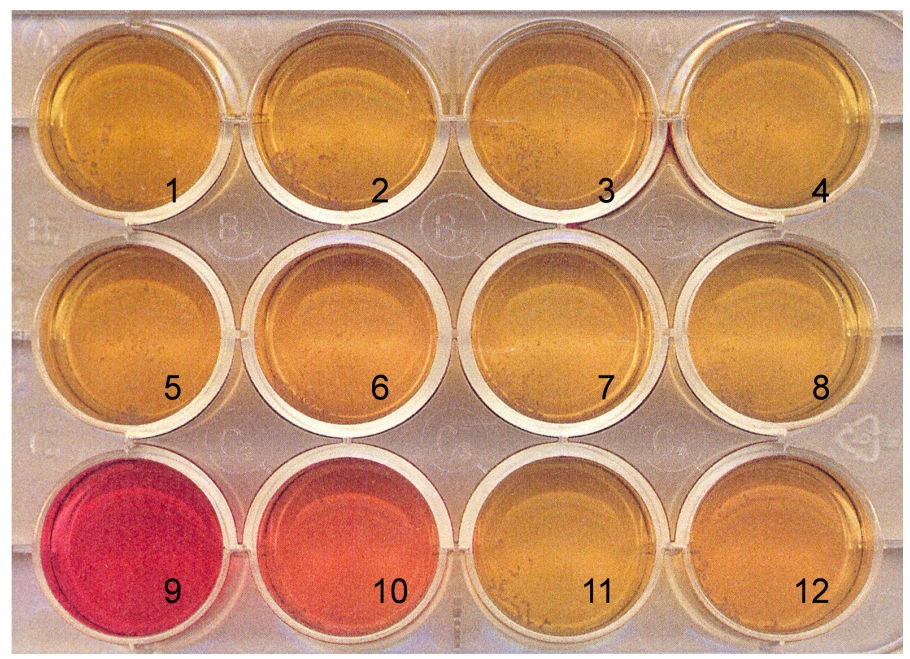
basal cells forming a myxoid to spindle tumor-like tis sue. Most probably these tumors originate from biphasic mammary gland stem-like cells, they could even be less differentiated but that needs to be proven. CD10 is a known marker for myoepithelial cells and all cells in our study were negative for this antibody (Leibl and Moinfar, 2006). Most likely, functional myoepithelial cells are only present during lactation and thus the term basal cells is to prefer in breast cancer terminology (Hellmén, 1996).

CD $44^{+}$CD24-llow cells have been found to correspond to breast cancer stem cells (Al-Hajj, et al., 2003). In the present study, we found that most cells were positive for CD44 and thus not valuable to separate different cell populations. The expression of CD44 was more up regulated in benign canine mammary tumors than in malignant ones (Paltian, et al., 2009). CD44 is associated with cell

Fig. 12. Filtrate cells form spheroids but the trypsin treated spheroids failed to re-grow. To study the capacity of spheroid formation we seeded the CMT-U229 avl 2 (passage 120) in enriched DMEM medium and cultured the cells in a spinner flask. After 14 days, the $30 \mu \mathrm{m}$ filters were used to separate the spheroids (retenate fraction, wells $\mathbf{1 , 2}$ ) from the single cells (filtrate fraction, wells $\mathbf{3 , 4}$ ). The spheroids were treated with trypsin for 10 minutes at $+37^{\circ} \mathrm{C}$ and the received retenate and filtrate were seeded in doublet wells. Once again these spheroids were treated with trypsin $2 x$ 10 minutes and the formed retenate and filtrate were seeded in doublet wells and cultured for 20 days in a Hydro Cell plate. The spheroids that were trypsin treated for 10 minutes did re-grow; see wells (5-6), but after another 10 minutes of trypsin treatment the growth ceased; wells (9-10). Interestingly, filtrate cells from all wells $\mathbf{( 3 - 4 , 7 - 8 , 1 1 - 1 2 )}$ formed new spheroids and few single cells were seen. The yellowish color of the medium indicates that it was consumed and small spheroids can be seen in the lower part of these wells. 


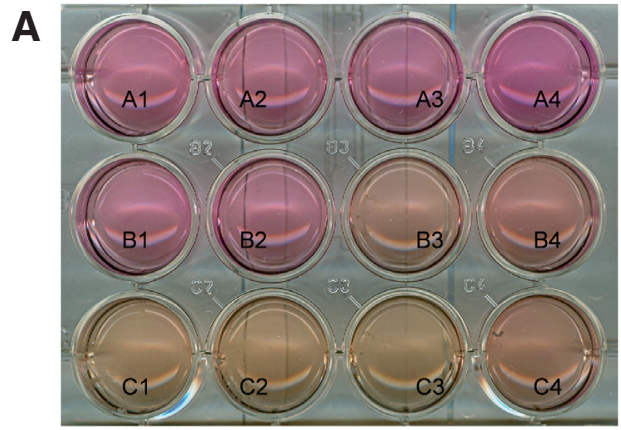

Fig. 13. Cancer stem-like cells do not form spheroids under serum free conditions. (A) Cells from sorted CD133+ (passage 7), were seeded in a Hydro Cell plate. Cells in wells A1-B2 were cultured in serum free RPMI1640 whereas in wells B3-C4 10\% fetal bovine serum was supplemented. One hundred cells were seeded in the wells A1-2 and B3-4; 1000 cells in wells A3-4 and C1-2; 10 000 cells were seeded in wells B1-2 and C3-4 and cultured for 27 days. No spheroids were formed in A1-B2; only single cells were seen (not shown, the red color of the medium indicates that it has

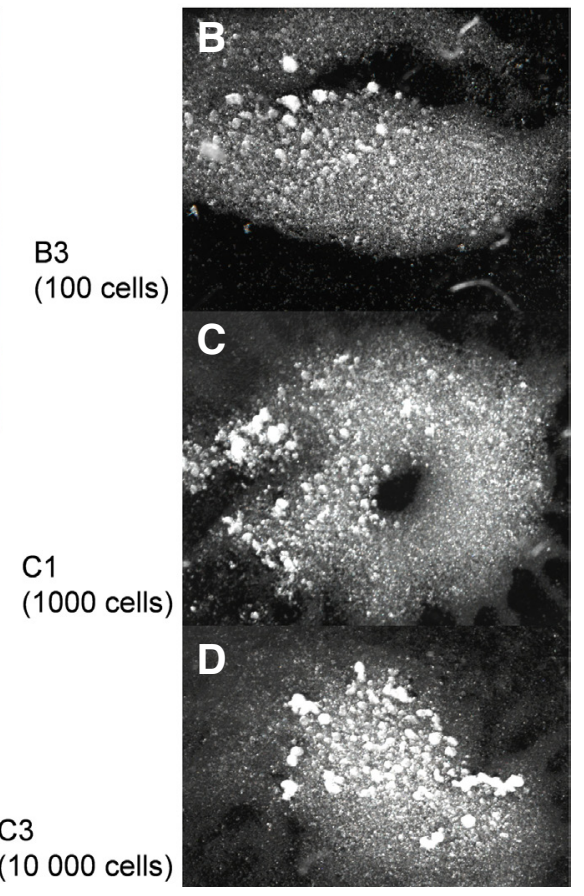
not been consumed). (B-D) Plenty of spheroids and single cells were found in wells (B3, C1 and C3) with added serum irrespective of the seeded cell concentration (B,C,D objective $x 4)$. form a micro milieu that we need to study further.

Our finding that the cells did not grow with devoid of serum is in agreement with another study of canine mammary tumors where no spheres were formed in the absence of growth factors (Michishita, et al., 2011). This might indicate the need for paracrine growth stimulation of the tumor cells to form spheroids in vitro.

In conclusion, if side population cells correspond to stem cells we have enriched tentative tumor stem-like cells from the CMT-U229 avl2 cell line derived from a canine mammary gland tumor. All the cellular markers that we have used indicate that the studied cell line, in particular when enriched for the SP cells, have stem cell characteristics.

\section{Materials and Methods}

\section{Cell culture}

The CMT-U229 cells were subcloned by cutting out a piece of a formed duct in the collagen type I culture (Hellmen, 1992) the cell clone was named avl2 (Fig. 1 A). For each spheroid forming experiment, approximately $3 \times 10^{6}$ cells were detached by trypsin-EDTA (SVA, Sweden) and filtered through a pre-separation 30 um filter (Macs, Miltenyi Biotec) and proliferation rather than to cancer stem-like cells in in vitro cultured canine mammary tumor cells (Blacking, et al., 2011). It might be that CD44 has another role in canine mammary tumorigenesis than in humans and mice. The expression profile found on the SP cells CD10 low/CD34+/CD44 $/$ CD24 ${ }^{\text {low }}$ and CD49f ${ }^{+}$support the idea that canine mammary tumor cells do contain a cell population of cancer stem-like cells.

All our results in this study are in agreement with the literature and in favor of a stem cell signature on the mammary tumor cell line. However, we have not yet tested the tumorigenecity in mice of the SP cells, non-SP cells or of the cells sorted for the different CD markers in relation to the original CMT-U229 avl2 cells.

One of our interesting findings is the presence of single cells in addition to the spheroids. There seemed to be a balance between the number of spheroids and the number of single cells. Further, in cultures with cells enriched for SP cells, the spheroids became large and after repeated SP analyses the cells were no longer possible to detach with trypsin. In addition it appears as in these large spheroids an extracellular matrix is formed (Fig. 6D). Interestingly, hyaluronic acid hydrogel is shown to support long-term self renewal of human embryonic stem cells in the presence of conditioned medium from mouse embryonic fibroblasts but also to direct cell differentiation (Gerecht, et al., 2007). The finding that Oct4 was only expressed in the peripheral cells of the spheroids and free single cells in the spinner flasks is very interesting. This might indicate that the cells divide asymmetrically, which is another hallmark for stem cells. Cells more to the centre of the spheroids may have started their differentiation processes and thereof lack the stem cell factor Oct4. Compared to Oct4 the stem cell marker Sox2 had a broader expression pattern in the spheroids together with Ki-67. Only cells in the centre of the spheroids stained positive to the antibody directed against Cleaved Caspase-3, which demonstrates apoptosis. These findings indicate that the spheroids the cells were transferred to a spinner flask (Techne, UK) and allowed to form spheroids for usually 7 days at $37^{\circ} \mathrm{C}$ in $5 \% \mathrm{CO}_{2}$ atmosphere (Kebo, Biomed, Sweden).

Initially, the cells were cultured in RPMI1640 supplemented with 10\% fetal bovine serum (FBS), (Invitrogen, Carlsbad, CA), L-glutamine and penicillin plus streptomycin (National Veterinary Institute, Uppsala, Sweden). Single sorted cells, and onwards, were cultured in DMEM Glutamax (GibcoBRL\#61965-026) medium with supplements, 15\% FBS (GibcoBRL 10270-106), Hepes buffer (1M), (GibcoBRL 15630-056), Sodium pyrovate (100 mM), (GibcoBRL 11360-039), Monothioglycerol (98\%), (Sigma $\mathrm{M}-6145)$ and ESGRO LIF (10 $\mathrm{U} / \mathrm{ml})$, (Mediqip ESG1107), herein named as "enriched DMEM medium". One percent agarose-coated petri dishes were used in some experiments to avoid the cells to attach to the bottom.

\section{Tumorigenicity of CMT-U229 avl2 cells in nude mice} avl2 cells at passage 131 and two mice were inoculated with $2,4 \times 10^{6}$ CMT-U229 avl2 at passage 133. Cells used for inoculation were washed twice in PBS, suspended in 100 $\mu$ l PBS and inoculated subcutaneously in the flank of the mice. The mice were euthanasied after three to 6 weeks when the tumor reached a diameter close to $1 \mathrm{~cm}$. The tumors were fixed in $4 \%$ phosphate buffered formaldehyde and embedded in paraffin. The sections were stained with hematoxylin and eosin (H\&E). At autopsy, tissue from the brain, all lung lobes, myocardium, liver, spleen, kidney, adrenal gland, uterus, ovary and submandibular lymph nodes, sternal lymph node, accessory axillary lymph nodes, popliteal lymph nodes and the subiliac lymph nodes were fixed and examined for metastases. No metastases were found in any of the mice. The animal experiments were performed in accordance with protocols approved by the ethical committee, approval number C 350/97.

\section{Side population analysis and immunolabeling}

Cells for each side population experiment were handled as described above for spheroid formation. In addition to formed spheroids single to doublet cells were present (Fig. 1 B). The experimental design of the side
Four female Balb/c nu/nu mice (Bomholtgaard, Denmark) were used for in vivo experiments. Two mice were inoculated with 3,6 x 106 CMT-U229 
population analyses (SP) is shown in Fig. 3. The cells were harvested and filtered through the $30 \mu \mathrm{m}$ pre-separation filters. The retenates $(>30 \mu \mathrm{m})$ that comprised the spheroids, respectively the filtrates $(<30 \mu \mathrm{m})$ were handled separately. Briefly, cells from the retenate fraction as well as the filtrate fraction were washed and treated with trypsin-EDTA respectively to get single cell suspensions. $3 \times 10^{6}$ cells were incubated with Hoechst $(5 \mu \mathrm{g} / \mathrm{ml})$, with and without the blocking substance Verapamil $(50 \mu \mathrm{g} / \mathrm{ml})$ in a $+37^{\circ} \mathrm{C}$ water bath for 120 minutes. Cells were centrifuged and ice-cold cell culture medium was added. Propidiumiodide $(2 \mu \mathrm{g} / \mathrm{ml})$ was added to detect dead cells (Goodell, et al., 1996). When the SP analyses were combined with antibody labeling, cells were centrifuged and primary antibody was added in $100 \mu \mathrm{l} \mathrm{Hank's} \mathrm{buffered} \mathrm{salt} \mathrm{solution} \mathrm{(HBSS)} \mathrm{with} 2 \%$ FBS and incubated on ice for 15 minutes. For unlabeled primary antibodies the procedure was repeated with the secondary antibody. Finally $900 \mu \mathrm{l}$ HBSS was added and the cells were kept on ice until analyzed. The following primary monoclonal rat anti-mouse antibodies were used: CD10 (ab1165), CD24 (555426), CD34 (559369), CD44 (553134), CD49f (555734) and sca-1 (553336), and their corresponding rat $\lg G$ isotypes $\lg G 1$, IgG2a or $\lg G 2 b$ and secondary antibodies rat anti-mouse FITC or PE labeled, all from BD Biosciences. The CD133 antibody was from Abcam (ab5558). The SP analyses were done in total about 30 times and the antibody labeling experiments by flow cytometry were performed about 20 times. All immunolabeling analyzed by flow cytometry were repeated at least once. Canine bone marrow cells were used as positive control for the CD34 flow cytometric studies.

\section{Flow cytometry}

The flow cytometric analyses and cell sorting was performed on a BD FACSVantage DiVa flow cytometer (BD, San Jose, CA), equipped with a Coherent Enterprise II laser (Coherent, Santa Clara, CA) for UV and 488 nm excitation. $\mathrm{HO} 342$ blue fluorescence was detected with a 424/24nm filter and $\mathrm{HO} 342$ red fluorescence using a 675/20 filter. For experiments where the cells were antibody stained, standard FITC $(530 / 30)$ or PE $(585 / 42)$ filters were used. Sort settings were: 90um nozzle, $20 \mathrm{psi}$, and $37 \mathrm{kHz}$.

\section{PKH26}

A PKH26 Red Fluorescent cell Linker Kit (Sigma) was used according to the manufacturer on clone $2 \mathrm{G} 9$ from the single cell sorted CMT-U229 avl2 cells (Fig. 3). In brief, cells in single cell suspension were centrifuged; the dye in diluent $\mathrm{C}$ was added and incubated in room temperature for 3 minutes. An equal volume of serum was added to stop the staining reaction. Spheroids were formed in agarose-coated petri dishes and in spinner flasks. The formed spheroids were analysed at day 12 . Spheroids were washed and the staining was confirmed in a confocal microscope (Zeiss 510 Meta).

\section{Immunocytochemistry and immunohistochemistry}

For immunocytochemistry and immunofluorescence, cells were cultured on cover slips and fixed in $4 \%$ paraformaldehyde (PFA). For immunohistochemistry, spheroids were fixed in 4\% PFA or phosphate buffered formaldehyde, embedded in agarose and thereafter in paraffin. Paraffin sections were dried over night and the slides were placed in antigen unmasking solution (VECTOR, Burlingame, CA) and boiled in a decloaking chamber (Biocare Medical). The primary monoclonal rat anti-mouse antibodies CD24 (555426) and CD49f (555734) and their corresponding rat IgG isotypes IgG2a or IgG2b were from BD Biosciences. The CD133 (ab5558) and Oct4 (ab19857) antibodies were from abcam, Sox2 (AB5603) from Chemicon, and Ki-67 (M7240) from Dako (Glostrup, Denmark). The Cleaved Caspase-3 (Asp175, 9661) antibody was from Cell Signaling. For all immunohistochemical analysis, positive and negative controls were used; for Sox2 the human glioma cell line U-2987MG; for Oct4, embryoid bodies from mouse embryonic stem cells; for Ki67 and Asp175 canine mammary gland, respectively. All slides were incubated overnight $\left(4^{\circ} \mathrm{C}\right)$ with the primary antibody. The ABC-Elite system was used for detection (Vector laboratories, CA, USA) and Nova RED (Vector laboratories) was used as chromogen for the paraffin embedded spheroids. All immunocytoand immunohistochemistry were repeated at least once.

\section{Low cell binding cultures}

We sorted both retenate $(2.6 \%)$ and filtrate $(0.6 \%)$ cells that were positively labeled with CD133. The sorted filtrate cells did not survive but the retenate cells were further cultured in enriched DMEM medium for 26 days (during this time period they were passaged four times), thereafter the CD133 sorting procedure was repeated but this time the CD133+ cells were sorted directly into a 24 well low cell binding plate (Hydro Cell, CellSeed Inc. Tokyo, Japan). The sorted cells formed spheroids and were allowed to grow for 21 days.

\section{Trypsin treatment and re-culturing of spheroids}

To study the capacity of spheroid formation CMT-U229 avl2 cells (passage 120) were seeded in enriched DMEM medium and cultured in a spinner flask. After 14 days the $30 \mu \mathrm{m}$ filters were used to separate the spheroids (retenate fraction) from the single cells (filtrate fraction). The spheroids were treated with trypsin for 10 minutes at $+37^{\circ} \mathrm{C}$ and the received retenate and filtrate were seeded in doublet wells. Once again these spheroids were treated with trypsin $2 \times 10$ minutes and the formed retenate and filtrate were seeded in doublet wells and cultured for 20 days in a Hydro Cell plate.

\section{Serum free cell cultures}

For spheroid studies in serum free medium, CD133+ sorted spheroid cells (passage 6) were seeded in Hydro Cell plates. The cells were cultured in doublets with 100, 1000 and 10000 cells per well, in RPMl1640 medium, with and without $10 \%$ FBS, for 27 days respectively (Fig. 13).

\section{Acknowledgements}

We thank the undergraduate students Elvira Santic and Rebecka Strandberg for their contribution to this study within the frame of their degree projects. We also thank the Swedish University of Agricultural Sciences for Strategic grants (to EH) and The Swedish Children's Cancer Foundation, The Göran Gustafsson Foundation and Åke Wibergs Foundation (to MF). Thanks are also given to the Department of Immunology, Genetics and Pathology at Uppsala University where the research was performed.

\section{References}

ADAMSKI, D., MAYOL, J. F., PLATET, N., BERGER, F., HERODIN, F. and WION, D. (2007). Effects of Hoechst 33342 on $\mathrm{C} 2 \mathrm{C} 12$ and $\mathrm{PC} 12$ cell differentiation. FEBS Lett 581: 3076-3080.

AL-HAJJ, M., WICHA, M. S., BENITO-HERNANDEZ, A., MORRISON, S. J. and CLARKE, M. F. (2003). Prospective identification of tumorigenic breast cancer cells. Proc Natl Acad Sci USA 100: 3983-3988.

ALVI, A. J., CLAYTON, H., JOSHI, C., ENVER, T., ASHWORTH, A., VIVANCO, M. M., DALE, T. C. and SMALLEY, M. J. (2003). Functional and molecular characterisation of mammary side population cells. Breast Cancer Res 5: R1-8.

BEHBOD, F., XIAN, W., SHAW, C. A., HILSENBECK, S. G., TSIMELZON, A. and ROSEN, J. M. (2006). Transcriptional profiling of mammary gland side population cells. Stem Cells 24: 1065-1074.

BLACKING, T. M., WATERFALL, M. and ARGYLE, D. J. (2011). CD44 is associated with proliferation, rather than a specific cancer stem cell population, in cultured canine cancer cells. Vet Immunol Immunopathol 141: 46-57.

CARIATI, M., NADERI, A., BROWN, J. P., SMALLEY, M. J., PINDER, S. E., CALDAS C. and PURUSHOTHAM, A. D. (2008). Alpha-6 integrin is necessary for the tumourigenicity of a stem cell-like subpopulation within the MCF7 breast cancer cell line. Int J Cancer 122: 298-304.

CHEN, M. S., WOODWARD, W. A., BEHBOD, F., PEDDIBHOTLA, S., ALFARO, M. P., BUCHHOLZ, T. A. and ROSEN, J. M. (2007). Wnt/beta-catenin mediates radiation resistance of Sca1+ progenitors in an immortalized mammary gland cell line. J Cell Sci 120: 468-477.

CLARKE, R. B., SPENCE, K., ANDERSON, E., HOWELL, A., OKANO, H. and POTTEN, C. S. (2005). A putative human breast stem cell population is enriched for steroid receptor-positive cells. Dev Biol 277: 443-456.

CLAYTON, H., TITLEY, I. and VIVANCO, M. (2004). Growth and differentiation of progenitor/stem cells derived from the human mammary gland. Exp Cell Res 
297: 444-460.

Cocola, C., ANAstasi, P., Astigiano, S., Piscitelli, E., PEluCChi, P., VILARDO, L., BERTOLI, G., BECCAGLIA, M., VERONESI, M. C., SANZONE, S., et al., (2009). Isolation of canine mammary cells with stem cell properties and tumour-initiating potential. Reprod Domest Anim 44 Suppl 2: 214-217.

DONTU, G., ABDALLAH, W. M., FOLEY, J. M., JACKSON, K. W., CLARKE, M. F., KAWAMURA, M. J. and WICHA, M.S. (2003). In vitropropagation and transcriptional profiling of human mammary stem/progenitor cells. Genes Dev 17: 1253-1270.

DOYLE, L. A. and ROSS, D. D. (2003). Multidrug resistance mediated by the breast cancer resistance protein BCRP (ABCG2). Oncogene 22: 7340-7358.

ERIKSSON, M., GUSE, K., BAUERSCHMITZ, G., VIRKKUNEN, P., TARKKANEN, M. TANNER, M., HAKKARAINEN, T., KANERVA, A., DESMOND, R. A., PESONEN, S., et al., (2007). Oncolytic adenoviruses kill breast cancer initiating CD44+CD24-/ low cells. Mol Ther 15: 2088-2093.

GERECHT, S., BURDICK, J. A., FERREIRA, L. S., TOWNSEND, S. A., LANGER, R. and VUNJAK-NOVAKOVIC, G. (2007). Hyaluronic acid hydrogel for controlled self-renewal and differentiation of human embryonic stem cells. Proc Natl Acad Sci USA 104: 11298-11303.

GOODELL, M. A., BROSE, K., PARADIS, G., CONNER, A. S. and MULLIGAN, R. C. (1996). Isolation and functional properties of murine hematopoietic stem cells that are replicating in vivo. J Exp Med 183: 1797-1806.

HELLMEN, E. (1992). Characterization of four in vitro established canine mammary carcinoma and one atypical benign mixed tumor cell lines. In vitro Cell Dev Biol 28A: 309-319.

HELLMÉN, E. (1996). The patogenesis of canine mammary tumors. Cancer J. 9: 282-286.

HONSCHA, K. U., SCHIRMER, A., REISCHAUER, A., SCHOON, H. A., EINSPANIER, A. and GABEL, G. (2009). Expression of ABC-transport proteins in canine mammary cancer: consequences for chemotherapy. Reprod Domest Anim 44 Suppl 2: 218-223.

LEIBL, S. and MOINFAR, F. (2006). Mammary NOS-type sarcoma with CD10 expression: a rare entity with features of myoepithelial differentiation. Am J Surg Pathol 30: 450-456.

LIAO, M. J., ZHANG, C. C., ZHOU, B., ZIMONJIC, D. B., MANI, S. A., KABA, M., GIFFORD, A., REINHARDT, F., POPESCU, N. C., GUO, W., et al., (2007). Enrichment of a population of mammary gland cells that form mammospheres and have in vivo repopulating activity. Cancer Res 67: 8131-8138.

MICHISHITA, E., GARCES, G., BARRETT, J. C. and HORIKAWA, I. (2006). Upregulation of the KIAA1199 gene is associated with cellular mortality. Cancer Lett 239: 71-77.

MICHISHITA, M., AKIYOSHI, R., YOSHIMURA, H., KATSUMOTO, T., ICHIKAWA, H., OHKUSU-TSUKADA, K., NAKAGAWA, T., SASAKI, N. and TAKAHASHI, K. (2010). Characterization of spheres derived from canine mammary gland adenocarcinoma cell lines. Res Vet Sci. 91: 254-260.

PALTIAN, V., ALLDINGER, S., BAUMGARTNER, W. and WOHLSEIN, P. (2009) Expression of CD44 in canine mammary tumours. J Comp Pathol 141: 237-247.

PATRAWALA, L., CALHOUN, T., SCHNEIDER-BROUSSARD, R., ZHOU, J., CLAYPOOL, K. and TANG, D. G. (2005). Side population is enriched in tumorigenic, stem-like cancer cells, whereas ABCG2+ and ABCG2- cancer cells are similarly tumorigenic. Cancer Res 65: 6207-6219.

PONTI, D., COSTA, A., ZAFFARONI, N., PRATESI, G., PETRANGOLINI, G., CORADINI, D., PILOTTI, S., PIEROTTI, M. A. and DAIDONE, M. G. (2005). Isolation and in vitro propagation of tumorigenic breast cancer cells with stem/progenitor cell properties. Cancer Res 65: 5506-5511.

SCHULENBURG, A., ULRICH-PUR, H., THURNHER, D., EROVIC, B., FLORIAN, S., SPERR, W. R., KALHS, P., MARIAN, B., WRBA, F., ZIELINSKI, C. C., et al., (2006). Neoplastic stem cells: a novel therapeutic target in clinical oncology. Cancer 107: 2512-2520.

SHACKLETON, M., VAILLANT, F., SIMPSON, K. J., STINGL, J., SMYTH, G. K., ASSELIN-LABAT, M. L., WU, L., LINDEMAN, G. J. and VISVADER, J. E. (2006). Generation of a functional mammary gland from a single stem cell. Nature 439 : 84-88.

SLEEMAN, K. E., KENDRICK, H., ASHWORTH, A., ISACKE, C. M. and SMALLEY, M. J. (2006). CD24 staining of mouse mammary gland cells defines luminal epithelial, myoepithelial/basal and non-epithelial cells. Breast Cancer Res 8: R7.

SMALLEY, M. J. and CLARKE, R. B. (2005). The mammary gland "side population": a putative stem/progenitor cell marker? J Mammary Gland Biol Neoplasia 10: 37-47.

STINGL, J., EIREW, P., RICKETSON, I., SHACKLETON, M., VAILLANT, F., CHOI, D., LI, H. I. and EAVES, C. J. (2006). Purification and unique properties of mammary epithelial stem cells. Nature 439: 993-997.

VILLADSEN, R., FRIDRIKSDOTTIR, A. J., RONNOV-JESSEN, L., GUDJONSSON, T., RANK, F., LABARGE, M. A., BISSELL, M. J. and PETERSEN, O. W. (2007). Evidence for a stem cell hierarchy in the adult human breast. J Cell Biol177: 87-101.

WELM, B. E., TEPERA, S. B., VENEZIA, T., GRAUBERT, T. A., ROSEN, J. M. and GOODELL, M.A. (2002). Sca-1 (pos) cells in the mouse mammary gland represent an enriched progenitor cell population. Dev Biol 245: 42-56.

WOODWARD, W. A., CHEN, M. S., BEHBOD, F. and ROSEN, J. M. (2005). On mammary stem cells. J Cell Sci 118: 3585-3594.

WRIGHT, M. H., CALCAGNO, A. M., SALCIDO, C. D., CARLSON, M. D., AMBUDKAR, S. V. and VARTICOVSKI, L. (2008). Brca1 breast tumors contain distinct CD44+/CD24- and CD133+ cells with cancer stem cell characteristics. Breast Cancer Res 10: R10.

ZUCCHI, I., SANZONE, S., ASTIGIANO, S., PELUCCHI, P., SCOTTI, M., VALSECCHI, V., BARBIERI, O., BERTOLI, G., ALBERTINI, A., REINBOLD, R. A., et al., (2007). The properties of a mammary gland cancer stem cell. Proc Natl Acad Sc USA 104: 10476-10481. 


\section{Further Related Reading, published previously in the Int. J. Dev. Biol.}

The mammary myoepithelial cell

Mejdi Moumen, Aurélie Chiche, Stéphanie Cagnet, Valérie Petit, Karine Raymond, Marisa M. Faraldo, Marie-Ange Deugnier and Marina A. Glukhova

Int. J. Dev. Biol. (2011) 55: 763-771

Cancer stem cells and angiogenesis

Yue Zhao, Qi Bao, Andrea Renner, Peter Camaj, Martin Eichhorn, Ivan Ischenko, Martin Angele, Axel Kleespies, Karl-Walter Jauch and Christiane Bruns

Int. J. Dev. Biol. (2011) 55: 477-482

Casein kinase I epsilon somatic mutations found in breast cancer cause overgrowth in Drosophila Tomas Dolezal, Katerina Kucerova, Jana Neuhold and Peter J. Bryant

Int. J. Dev. Biol. (2010) 54: 1419-1424

Reprogramming of melanoma cells by embryonic microenvironments

Alejandro Díez-Torre, Ricardo Andrade, Cristina Eguizábal, Elixabete López, Jon Arluzea, Margarita Silió and Juan Aréchaga Int. J. Dev. Biol. (2009) 53: 1563-1568

MMTV-trBrca1 mice display strain-dependent abnormalities in vaginal development Kaylene J. Simpson, Mas R. Wati, Andrew J. Deans, Geoffrey J. Lindeman and Melissa A. Brown Int. J. Dev. Biol. (2004) 48: 675-678

$$
5 \text { yr ISI Impact Factor }(2010)=2.961
$$

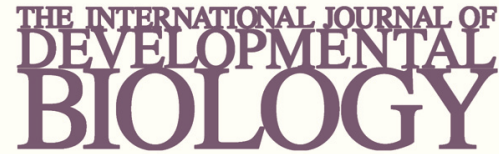

Volume 54 Nos. 6/7

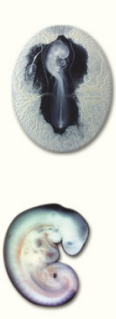

Developmental Hematopoiesis
Special Issue
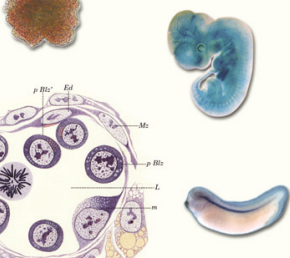

(1)
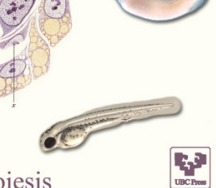
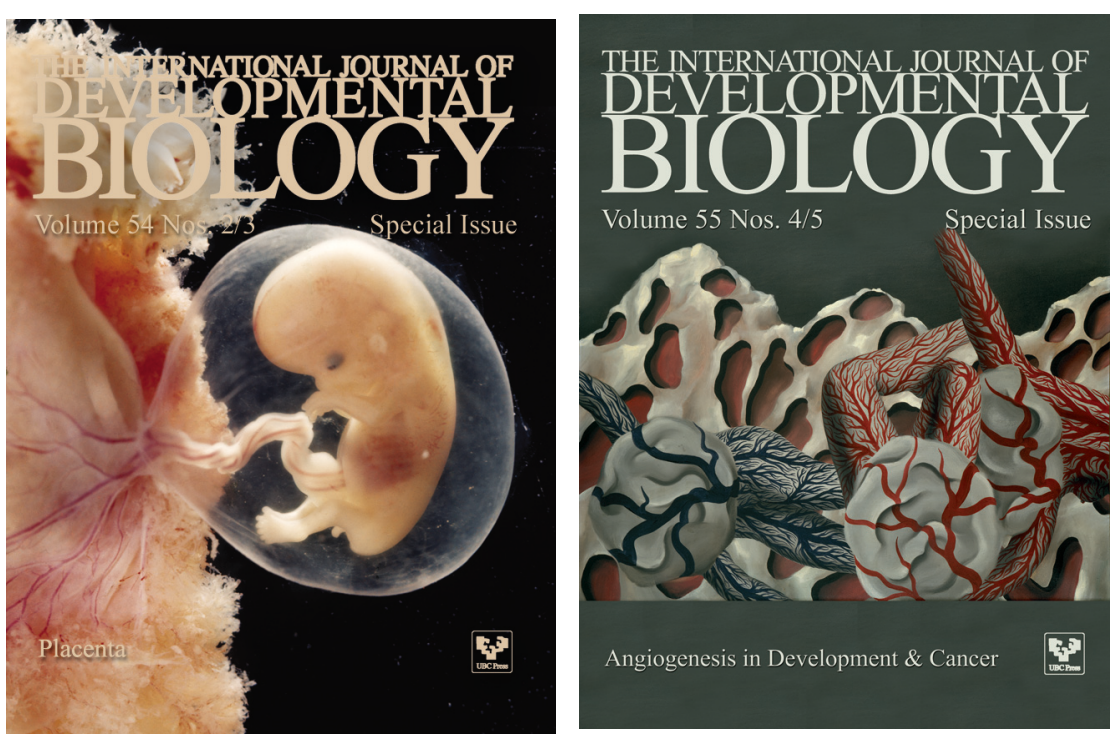